\title{
Vestnorden. A functional region?
}

\author{
Grétar Thór Eythórsson, professor in Government and Methodology at \\ University of Akureyri and Gestur Hovgaard, associate professor in Social \\ Sciences at University of The Faroe Islands
}

\begin{abstract}
This article discusses the issue of what kind of a region Vestnorden is. The need for such a discussion arises from the challenges posed by globalisation for the idea and construction of the West Nordic space, and the need to observe how this regional unit counters these processes. The article is based on an analytical framework which presupposes that a functional region has to consist of four elements. First, whether the space has its own institutions for decision making; second, how far there is economic complementarities among the involved nations and territories; third, to what degree they have common economic interests; and finally, to what extent social, cultural and historical ties exist between the territories involved. The article argues that there is an urgent need to discuss and reorient the institutional functionality of Vestnorden as a regional unit.
\end{abstract}

Keywords: Vestnorden / West Nordic, Region, Macro-region, Trans-region.

\section{Introduction}

The purpose of this article is to identify and discuss the regional characteristics of West Nordic co-evolution and cooperation, with a view to produce a first conceptual framework for understanding the status and future possibilities of the West Nordic as a regional unit.

The broader background of this topic lies in the new mosaic of regions and regional co-operation entities that we have seen arising across Europe over the last few decades (Association of European Border Regions 1999; Lundqvist and Persson 1993). This

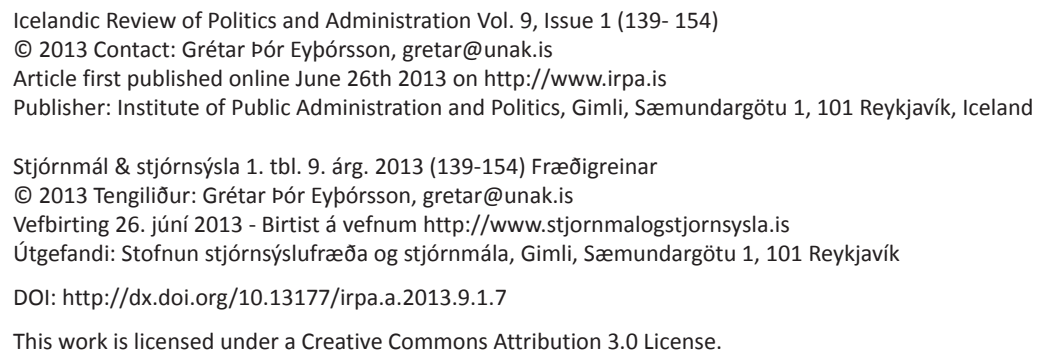




\section{STJÓRNSÝSLA}

evolution has been prompted by fundamental changes in the structures of nation-states, changes in business cycles and technologies, in environment and security issues, as well as by changes in cultural habits and identities (Storper, 1997). One outcome of this trend has been the slow but steady institutionalization of several West Nordic regional bodies, i.e. frameworks incorporating the Faroe Islands, Iceland and Greenland, but also in some contexts including Norwegian regional units.

In the first wave of region-building developments, during the 1980s and 1990s, the West Nordic players' most usual partners in international relations - the Nordic community and the EU - widened their sphere of interest towards the East, notably towards the Baltic and the Barents Sea region. While these changes tended more or less to leave the West Nordic space out on the periphery of events, things have turned out very differently in the more recent changes in regional affairs.

Around the turn of the twenty-first century the effects of environmental changes in the Polar North became still more apparent. These changes have come from the melting of the polar ice cap and the inland ice of Greenland, which again are followed by a steady opening up of the Northern sea passages, and a heavily increased focus on possible resource extraction and other economic opportunities. Therefore we now see an increased interest from the Nordic community, the EU and many other national and international bodies towards the North. The founding of the Arctic Council in 1996 and its subsequent institutionalisation indicates the "big business" that is helping to generate this regional structure. The interest now being shown by China and former colonial powers in Europe towards the changes in the Arctic only reinforces the argument (Sakhuja 2011; Baltic Rim Economies 2011).

For the reasons mentioned, the communities of the West Nordic space now find themselves in the middle of a new melting pot, and therefore it is a pressing question whether and how the West Nordic region can address itself to this new agenda. As already argued, however, the prior need is to probe the fundamental characteristics of Vestnorden as a region. For a start, the institutional structure of Vestnorden seems rather confusing. An illustrative example is that Vestnorden is most often referred to as a grouping of Greenland, Iceland and the Faroe Islands. This is for instance reflected in the West Nordic Parliamentarian Committee (WNPC) ${ }^{1}$, which tells us that these three countries constitute some sort of a political unit. Historically and culturally speaking, West Norway and North Norway should be included this context as a recent volume on the West Nordic reminds us (Thór et.al. 2012). In other fora, the same three countries and Coastal Norway are collectively referred to as the West Nordic region. Coastal Norway refers to not only north and west Norway, but southern Norway as well. This region is termed the "NORA-region" (OECD Territorial Reviews 2011).

This mismatch raises the critical question of what constitutes Vestnorden as a region. How is it constructed in terms of political, economic and cultural elements, working in conjunction, or perhaps separately? Also, how can we understand the present functionality of the different contexts in which this regional structure is included? 
Figure 1. Regions in Vestnorden 2010 (Map: Nordregio)

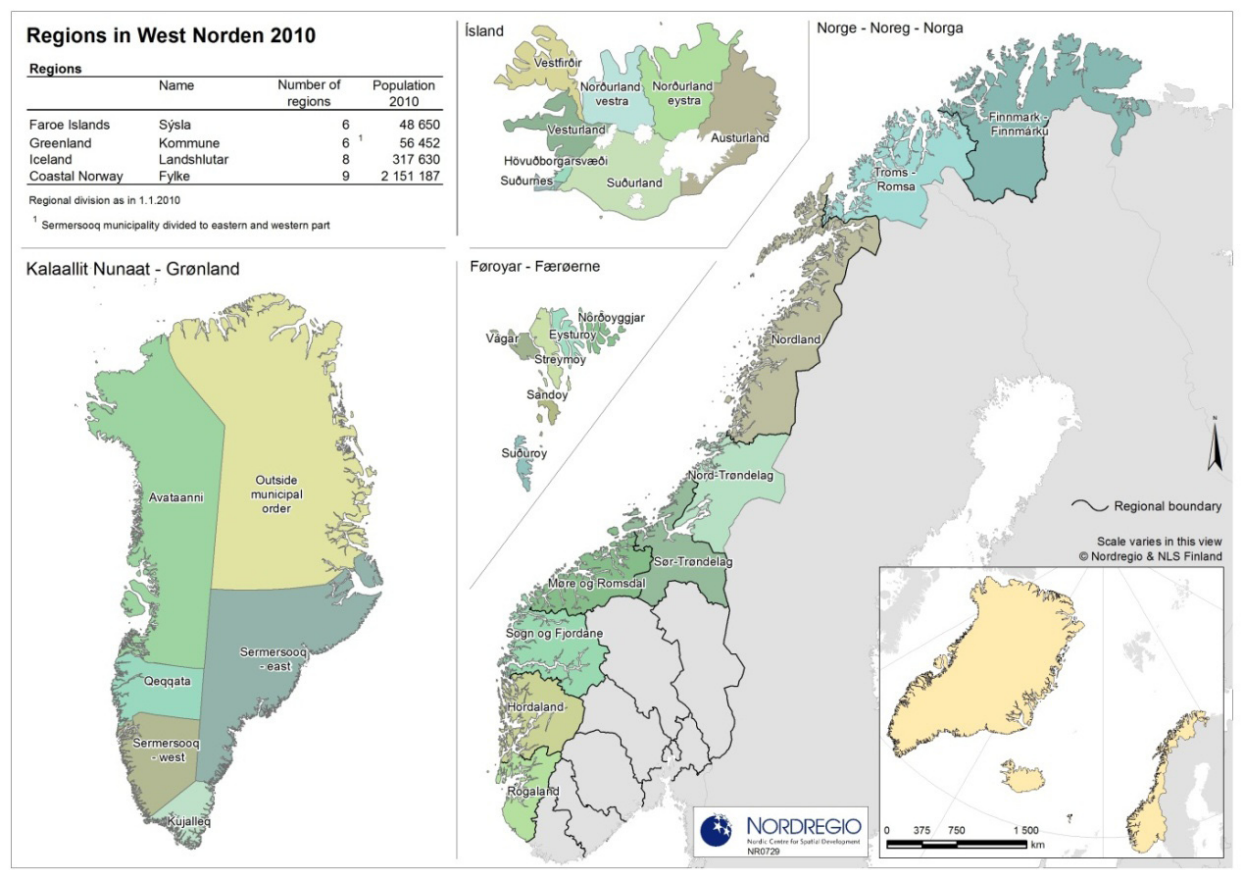

The Faroes is a group of 18 islands out of which 17 are populated. The Faroes lie $300 \mathrm{~km}$ northwest of The Shetland Islands, $450 \mathrm{~km}$ southeast of Iceland and $675 \mathrm{~km}$ southwest of Norway. The total land area is $1397 \mathrm{~km}^{2}$. In January 2013 the population was 48.193, distributed among 30 municipalities, with about 41 percent living in the capital, Tórshavn. ${ }^{2}$ The Faroes is an industrialised country, with a living standard comparable to other Nordic countries. In 2009, the GDP per capita was 29.997 USD, which places the islands in the middle of the Nordic family. Data for the year of 2011 show that about 71,5 per cent worked in the tertiary sector, 18 per cent in the secondary sector and 10,6 per cent in the primary sector (Hagstova Føroya 2012).

Greenland is the biggest island in the world and part of the North American continent, northeast of Canada. The northernmost point is Kap Morris Jesup, only $740 \mathrm{~km}$ from the North Pole. The total land area is $2.166 .086 \mathrm{~km}^{2}$. In (2011), the population was 56.615, distributed among 4 municipalities, with about 37 per cent living in the municipality where the capital Nuuk, is located. ${ }^{3}$ In 2009, the GDP per capita was 22.612 USD, which puts Greenland at the bottom of the Nordic family. Data for the year of 2011 show that 82,7 per cent worked in the service sector, 12,4 per cent in the secondary sector, and 4,9 per cent in the primary sector (Greenland in figures 2013).

Iceland lies in the middle of the North Atlantic Ocean, between Greenland and Faroe Islands. The total land area is $103.000 \mathrm{~km}^{2}$. In January, 2006, the population went over 300.000 for the first time and, in 2012, stands at 320.000 across 74 municipalities. The capital, Reykjavík, has 120.000 inhabitants and, with its close surroundings included, the population is around 200.000 - over 60 per cent of the entire population. In 2009, the GDP per capita was 38.772 USD, which puts Iceland high on the Nordic list. In the year 2011, 75,7 per cent worked in the service sector, 18,4 per cent in the secondary sector, and 6 per cent in the primary sector (Statistical yearbook of Iceland 2012)

\section{The concept of region}

What a region is might for most people seem obvious, since we all live in at least one kind of regional structure, a physical unit, that we take as something natural or given. But since our main research question here concerns the issue of what constitutes Vestnorden as a region, we need to clarify this apparently self-explanatory concept in general terms. 


\section{STJÓRNSÝSLA}

The Winston Dictionary, Encyclopedic Edition defines region as "an indefinitely large section of land or space" or as a "country or district". This tells us that a region can by definition be both land and space, which means it can also be sea or water. A region can be a unit within a state or across states. Taking that into account, we may posit that regions can be divided into three main categories, depending on how many states are involved in the region. The first category would be regions within a state, that is, regions existing within state boundaries and therefore intra-state regions. The second category would be regions crossing state boundaries, named trans-regions. To draw a distinction between regions that crosses borders between two states (trans-regions) and regions crossing the border of more than two states the category of macro-regions has been defined.

Taking our point of departure in Vestnorden as a whole, it is obvious that our matter of concern lies at the transnational or macro-regional level. Aalbu et.al. (1995) define a trans-region as a "constructivistic defined formation which crosses one or more state boundaries". For its functionality, i.e. how the diverse elements of the region in question form a whole (a system), this formation should have institutions for decision making, economic complementarity, common economic interests and to a certain degree, social interchange and a feeling of affinity among the populations. Put briefly, the main functional aspects of a trans-region are, according to this conceptualization, institutional, economic and social/historical/cultural (Aalbu et. al. 1995; Aalbu and Wiberg 1997). Following the line of thinking in 'new regional geography'; Bærenholdt (2007) discusses this definition and finds it advantageous to also place the region in a socio-economic and socio-cultural context. What Bærenholdt criticises is the failure to define the transregion as processes or practices, as distinct from a set of institutional formations.

In a report on macro-regions and macro-regional strategies from 2009, also Dubois et. al. (inspired by Hettne, 1996) emphasise the importance of looking at the processual dimensions, as Bærenholdt does. They claim that the definition of a region should be established regardless of the prefixes, be they macro, meso, micro or sub-national. Furthermore, they claim that the term 'region' can refer to anything between an administrative unit and a functional area (Dubois et. al. 2009). Their point is that macro-regions are more about practices and processes than physical objects. The strategies of stakeholders that lie behind the regionalization trend can change over time; thus, the units cannot be seen as static. They sum up by saying:

"...regions are basically social constructs in the worlds of both science and politics. Regions are 'constructed, deconstructed and reconstructed through interaction between various actors in response to changes in their internal and external environment on the basis of what is most appropriate for the pursuit of their commonly held goals". (Dubois et.al. 2009, 17)

If we accept a distinction between a trans-region and a macro-region, we would need to conclude that with three states included, a region must be a macro-region. Lindeborg 


\section{STJÓRNMÁL \\ STJÓRNSÝSLA}

(2011) writes that a macro-region is a larger cross-border region, mostly transnational even if existing in a national context, that is, being an intra-state region.

Whatever the definition, the important issue here is that regions are physical units which are being shaped by social practices and processes, involving power relations and different levels of scale. The current status then of any region will be the outcome of practices and processes, and what we need here is to discuss the specific effects or the current standing of these same practices and processes. Therefore, to define to what extent the West Nordic is a region in the four senses mentioned by Aalbu et.al. is sufficient for the purpose of this paper.

\section{Tracking Vestnorden as a region}

The Faroe Islands, Greenland and Iceland are in many ways different societies. One of the marked differences is that Greenlanders by origin belong to the Inuit culture, while Icelanders and Faroese belong to the Norse culture. Although a "small state", Iceland is far bigger in population than the two others and is also the only fully sovereign state among the three countries. At the same time they have a shared history and commonalities that ties them together, which again are important for the arguments presented in this article. ${ }^{4}$

For hundreds of years Vestnorden has had institutional connections with the Nordic countries east of the Atlantic Ocean (East Norden). These have primarily been connections with Denmark, which was the colonial power of all three countries from 1380. In 1814, when Norway joined the union with Sweden, The Faroes, Greenland and Iceland became a part of the Danish state. Later, Iceland became a sovereign state in 1918 and a republic in 1944. The Faroes have had Home Rule since 1948 and Greenland obtained Home Rule in 1979 and in 2009 a new Self-Governing Act was passed. The common history of the three countries includes the adoption of Christianity around year 1000, the Reformation in the seventeenth century, and last, but not least, the common experience of a Danish crown monopoly on trade for hundreds of years. Bærenholdt (2007, 68) argues that in modern times there are several commonalities among the West Nordic countries, such as national movements, traditions of local autonomy, the building of "the social state", and the development of modern fishery and tourism. These historical roots mean that tight cultural ties between the West Nordic countries have developed and that these countries are also integrated parts of the institutionalised "Nordic family" with its long tradition of inter-governmental cooperation.

One of the main arguments for seeing Vestnorden as a region lies in the special characteristics applied to the region. In this case, the common features are the concerned territories' small number of inhabitants, the scattered settlement pattern, the harsh climate, the division of the land masses by large sea spaces, their different forms of national integration, and their deep dependence on marine resources. For instance, the working group on "The West-Nordic in the Nordic Co-operation" in its report of May 2003, described the three West Nordic countries as an integrated part of Nordic cooperation with special challenges due to their special socio-economic characteristics such as long 


\section{STJÓRNSÝSLA}

distances, dependency on the sea, cold climate and small populations (Nordisk Ministerråd 2003, 8).

One systematic definition that has come close to encompassing the West Nordic area as a region is the one used for the Nordic Atlantic Cooperation (NORA). On the NORA webpage the following definition appears:

"The NORA Region includes the Faroe Islands, Greenland, Iceland, and coastal Norway (the 9 coastal counties of Norway, from Finnmark in the north to Rogaland in the south, and Svalbard). The region covers an area of land and sea that is larger than the continent of Europe, but at the same time scarcely populated. The distances between the four territories are vast and so is the distance between the NORA countries and the rest of the world. Despite the vast distances, the NORA countries are linked by shared characteristics, common challenges, and historical, institutional and cultural links. The NORA Region is furthermore situated between Europe and North America, as an entry way to the Arctic. This gives the region a strategically important position". 5

A similar, but more substantial definition of the NORA region is provided by OECD (OECD Territorial Review, 2011). Here the North Atlantic Region is defined as a group of territories strongly linked by shared characteristics, extreme peripherality, and historical, cultural and institutional links. It is considered as a transnational region consisting of the Faroe Islands, Greenland, Iceland and Coastal Norway - that is, the west coast of Norway from Rogaland County in the south up to Finnmark County in the north. The extreme peripherality of the region is emphasized by saying it is far away from the main world centers of trade and business, and much of the population (a total of 2,5 million) lives in small and remote settlements where aging populations and out-migration of young adults are a common problem (ibid.).

Thus in the OECD report, the justification for defining a single NORA region made up of Greenland, Iceland, the Faroes and Coastal Norway rests upon their: a) extreme peripherality with long distances, sparse populations, physical barriers, reduced accessibility and high transportation costs; b) historical, cultural, institutional links and common history; and c) similar economic potential, being rich in marine resources and having potential for eco-tourism, energy and mineral production.

Despite the various distinct approaches to define the characteristics and problems of the West Nordic region, a more substantial discussion on why Vestnorden exists as a region, is to our knowledge absent, and Vestnorden seems to be taken for granted as a region, so in what sense or to what extent is the West Nordic a region at all? 
Vestnorden. A functional region?

Grétar Thór Eythórsson and Gestur Hovgaard

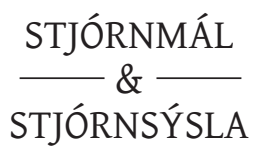

\subsection{West Nordic institutions for decision making}

West-Nordic regional co-operation is first and foremost institutionalised within the framework of the Nordic Council and the Nordic Council of Ministers. The Nordic Council was founded in 1952 and the Nordic Council of Ministers in 1971. In other words, institutionalised Nordic cooperation is older than the foundation of the European Economic Community (EEC). The Nordic passport union, the open Nordic labour market, voting rights for other Nordic citizens at local elections, and other civil rights, predate the formulation of the same rights in the European Union by many years (Baldersheim and Ståhlberg, 1999). ${ }^{6}$

The present structures of West Nordic cooperation can be seen as a leftover from the ambitious but failed NORDEK cooperation (Bærenholdt 2002), i.e. the ambition in the late 1960s to create a common Nordic market.

The story behind institutionalised West Nordic cooperation is that it was initiated by the practical experiences of cooperation between Faroese and east Icelanders in establishing a North Atlantic ferry link. In the mid 1970s the Faroese public authorities had purchased a car-ferry from Denmark, which by this co-operation, in the summer period was put into operation between the West-Nordic (Faroe Islands, Iceland and Norway) and the European mainland (Denmark in particular, but even Shetland/Scotland) (Arabo 2006).

The positive practical experiences from the ferry-link were used to foster the idea of expanding and developing West-Nordic co-operation, even inspired by the preceding Nordic cross border co-operations (Arabo 2006). On this background, several institutions that have the objective to strengthen cooperation among the West Nordic countries exist, of which the important ones, are Vestnordisk Rad (West Nordic Parliamentarian Committee), Vestnorden fonden (The West Nordic Fund) and NORA. These three institutional arrangements are generally considered as the principal pillars in the West Nordic cooperation system, and will be presented in the following.

\subsubsection{Vestnorden Fonden (The West Nordic Fund)}

The West Nordic Fund (WNF) was established in 1980, and one can say institutionalised West Nordic cooperation began with its formation. It is a fund established by the Scandinavian parliament for loans and guarantees to support joint business development in the West Nordic, and was originally established to address a number of contemporary problems of interregional cooperation. Companies physically placed in two different countries faced difficulties because their respective national structures were not designed to address bilateral tasks. Also it was not without significance that the Icelandic currency was quite unstable (Arabo 2006).

The fund has offices in all three countries and lends money on market terms to investments in all three countries on the condition that the investment has to do with cooperation among West Nordic firms. The main emphasis has been on the two smaller countries, the Faroes and Greenland. In 2011, the fund lent and granted 24.2 million DKK, of which 16.2 million went to the Faroes and 8 million to Greenland (Vestnordenfonden 2012). 


\subsubsection{Vestnordisk Råd (The West Nordic Parliamentarian Committee)}

The West Nordic Parliamentarian committee (WNPC) was founded in 1983 on the idea that practical cooperation should have a political foundation. Its main purpose is to cooperate on issues of common West Nordic interest, and consists of six parliamentarians from each country, i.e. Greenland, Iceland and the Faroes.

At the Annual Meeting, which is the principal decision making forum of the Council, the members' propositions are debated, resolutions are passed and are sent as recommendations to the respective national parliaments. Most resolutions and initiatives have through the years been within the cultural or fishery domains, but in recent years more and more of them have touched on research/education, energy and healthcare issues.

Thematic conferences have also been a considerable part of the activity of the council, and these conferences may also send recommendations to the respective national parliaments.

Showing parliamentarians' interest in a given issue, making resolutions and sending recommendations is the way for the council to act. It has no economic means to support or initiate any measures within the policy fields that it covers.

The expressed goals and aims of the West Nordic Council are:

- Cooperation for West Nordic interests

- Monitoring North Atlantic resources and culture

- Contributing to the development of West Nordic interests through the work of the respective parliaments, especially serious problems with resource allocation and pollution

- To cooperate with the Nordic Council

The West Nordic Council is the key forum for institutionalized West Nordic cooperation on a parliamentary level. Through cooperation in projects and various types of networking, inter-governmental cooperation also exists in various other sectors. Within the health sector, Iceland and Greenland/Faroes have contracts on the treatment of patients. Another sector is tourism, where organized cooperation exists through the North Atlantic Tourism Association (NATA). ${ }^{7}$ An annual common event within this cooperation is the Vestnorden Travel Mart, where companies in the West Nordic tourism sector promote their offerings towards the international community.

\subsubsection{NORA (North Atlantic Cooperation)}

NORA is one, and the latest, among the nine formalised regional co-operation frameworks within the Nordic Cooperation framework. Such Nordic regional co-operation has its roots in the 1960s, and was formalised with the creation of the first such structure, the North Calotte cooperation, in 1975. In the 1990s it became the norm that regional cooperation within Nordic cooperation mainly consisted of cross-border cooperation. 


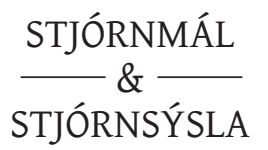

147

The aim of NORA is to contribute to the creation of a vital and dynamic North Atlantic region, by supporting collaboration between businesses and research and development of organizations in the region. ${ }^{8}$

The Nordic Council of Ministers supplemented by national grants from the four member countries, finances NORA. As noted above, the definition of the West Nordic region is widened by NORA to include Coastal Norway.

Since the beginning, NORA has gone a considerable distance towards helping its partners to meet the challenges of internationalization, especially the increased importance of regional economic cooperation. Many grants for networking and innovation activities through the years have firmly established the role of the organization in developing West Nordic cooperation. This positive role is highly stressed in an evaluation report from 2004 (Kvistgaard Consult, 2004). In 2010, NORA granted 6,1 million DKK to projects (NORA Annual Report 2011).

\section{Institutions for decision making?}

We have now identified three principal decision making organs in Vestnorden, one parliamentarian and two institutions that lend and grant money respectively to initiate economic development. They are covering different but complementary goals, and even supplemented by other formal arrangements covering the Vestnorden space. ${ }^{9}$

One common feature in the functioning of these institutions is that they have limited decision making power, most clearly reflected in the fact that WNPC does only have the authority to make recommendations to their respective national parliaments.

The financial support provided is normally small and does not constitute anything of great significance for the fate of the sectors concerned. Their impact can be seen as positive but not decisive.

Another common feature is that their focus is basically on internal West Nordic matters, a kind of extension of traditional regional policy towards a wider cross-border space, while many of their common interests are subject to international regulations and powers (see also later).

As such the decision making institutions of the West-Nordic follow the "low politics" line characteristic of Nordic Cooperation, which of course does not necessarily mean that they are weak or do not matter.

Most striking is the fact, that there are different structures and areas covering the West Nordic region. From the perspective of history, it was vital for first West Nordic co-operators to get the connections with Coastal Norway. The physical route of the North Atlantic Link was believed to be an important component in building institutional structures. A side from the cooperative potentials in common natural resources and tourism, the decentralized and highly developed Norwegian research and development sector was seen as an option for increasing the quality of such undertakings in the West Nordic context for common purposes. With NORA one can say that this idea was turned into reality, but with a different framework of governance. 


\section{STJÓRNSÝSLA}

\section{Economic complementarity and common economic interests}

At a conference in Geneva in 1960, the then British Minister of Fisheries, John Hare, said that there were only three Atlantic countries which were overwhelmingly dependent on the fishery: Iceland, Greenland and the Faroes (Jákupsstovu 1966, 70). This statement was based on information from a FAO-report about fish catches, which at that time for the three countries was 3 to 4 tonnes per capita per year. Despite great structural changes in the contemporary fisheries, their importance for these countries is still great.

The Faroese economy is still heavily based on fish export, about $90 \%$. But since the 1980s aquaculture development (Atlantic salmon) has grown considerably as a diversification strategy (Apostle et.al. 2002; Jacobsen 2011). Today the export of aquaculture products counts for nearly $30 \%$ of total export value and about $35 \%$ of the value of fish products.10 In 2008, 72 per cent of the total exports of Greenland were fish exports (OECD Territorial Review 2011, 45). In recent years development has created opportunities for large scale mining of great economic and geopolitical importance, something which creates optimism but large concerns as well.

Compared with the big Nordic countries, the Icelandic economy is quite one-sided, but it is more diversified than the other West Nordic ones. In 2012, fish exports were 42,2 per cent of the total exports, and products from energy consuming industries, that is mostly aluminium, accounted for 41,7 percent. ${ }^{11}$

It is clear that the economies of the West Nordic countries are heavily reliant on natural resources, with their fishing industries dominant. These figures portray onesided economies that do not seem to complement each other to any considerable extent (OECD Territorial Reviews 2011). The economic profiles normally expose their obvious weaknesses, which lie in openness, one-sidedness and small home markets. These problems have been apparent in repeated conjunctural ups and downs in modern history, followed by high migration patterns comparable to those well known from other smaller territories (Benedict, 1967). Today economic vulnerability together with the harsh consequences of modern mobilities poses fundamentally new challenges to island communities (Baldacchino, 2008), the West-Nordic included.

However, and despite their socio-economic weaknesses, the West Nordic countries have developed comparatively large public and private service sectors which contribute considerably to their wellbeing, and they have managed to become among the richest and most developed countries in the world. The well known argument put in front by Katzenstein $(1985,2003)$ that perceived vulnerability of small states creates a compensative culture of coordination and cooperation based on social partnerships - the Nordic/ Scandinavian welfare system being one of the prime examples - does also seem to count in the case of the West-Nordic (Hovgaard 2001; Bærenholdt 2007).

Tourism has been the most rapidly expanding branch in all three countries since 2000, and the same has been the case with the service sector in general (Sundström, 2006). Thus the range of economic differences is mainly restricted to the less one-sided economy of Iceland, which is now, in many ways, returning to its original staples, fishing, 


\section{STJÓRNMÁL \& \\ STJÓRNSÝSLA}

fish processing, farming and aluminium industry after the enormous financial expansion resulting in the dramatic collapse of the country's three biggest banks in the autumn 2008.

Economic complementarities should also be reflected in countries' trade with each other. By looking at the total import/export between the West-Nordic countries in 2011 we see that this is of low importance. For Iceland the share is $0,3-0,9$ percent, For Greenland this share is 1,1 - 2,6 percent and the highest share is for the Faroes 6,98,1 percent, mostly through trade with Iceland (Nordic Statistical Yearbook 2012, 110). On the other hand, the trade rates illustrate high dependency on import/export with Denmark in the Faroese case, and extreme dependency in the Greenlandic case. Iceland represents a far more open economy with relatively high import/export numbers to the EU (Nordic Statistical Yearbook 2012).

Looking at this evidence, we can hardly claim that economic complementarity exists within the West Nordic context. On the other hand the three countries have considerable economic interests in common. Tourism cooperation between the countries has been growing in some areas, such as flight connections between Iceland and Greenland - a direct flight connection between Reykjavík and Nuuk has been operating since 2007..$^{12}$ Two days a week there is a direct flight between Faroe Islands and Iceland, which has also made it possible relatively cheaply to travel between Greenland and the Faroe Islands. At least we may claim that common economic interests in that field are growing rather than declining, and some cooperative efforts can be found in other sectors too. Still, this is cooperation on a rather low level, leaving out many of the most obvious sectors of common economic interest like keeping common fishing zones sustainable, environmental protection and the like.

\section{The ties that bind: Social relations and affinity}

The hundreds of years of common history between the West Nordic include the common factor of institutional relations with Denmark - all having been Danish colonies or dependencies. The pre-history is the Nordic settlement and colonization of the three countries. The Faroes (in 1035) and Iceland (in 1262) initially fell under the Norwegian throne, but after Norway came under Danish rule in 1380, the West Nordic countries became a part of Denmark. Thus, these three countries have a long relationship with the Nordic family, especially Denmark; today with very different constitutional statuses, Iceland as an independent state, Greenland with a recent Self-governing status, and the Faroes as a home rule constituency. Although different statuses, the strong connection with Denmark is still apparent in modern institutional and socio-cultural relations. Bærenholdt (2007) argues that these common threads include the adoption of Christianity around the year 1000, the Reformation in the seventeenth century, and also the experience of the Danish trade monopoly which was dominant for hundreds of years. He also sees signs of a common background in modern times. For example, these countries had national movements, traditions of local self-government, and the foundation of the social state, as well as the development of modern fishing and tourism industries. 
These historical roots have in practice led to tight cultural relations among the West Nordic countries. Traces of this common heritage can also be found in the economic sector, probably most significantly by the Faroese tradition of fishing off the coasts of Greenland and Iceland - a tradition that sometimes meant temporary seasonal settlements (Arge 2002; Joensen 1987). The global whale history of Norway did also involve large engagements in the West Nordic, in particular Faroes and Iceland (Tønnessen 1967).

These commonalities also involve labour exchange, in part made possible by the open Nordic labour market and educational sectors. These arrangements have not the least been important at times of crisis, such as in the Faroes in the 1950s and 1990s. In those times great number of Faroese workers moved to Iceland, Greenland and other Nordic countries to make a living, Denmark in particular.

The cases mentioned are only a few illustrations of the fact that a common West Nordic identity is based on the practical experiences of people's involvement with each other. Experiences of this kind create personal and institutional relations that are important for the collective memory of any social coherence. Sometimes these experiences evolve into institutionalized structures, as was the case with the formation of the first West Nordic regional structures back in the late 1970s. So even though a West Nordic identity can be traced long way back in history, its institutionalization is still of a recent date.

At the same time, we need to be careful not to overstate the degree of a West Nordic identity. All the countries have strong cultural relations within other international social contexts. Greenlanders have their affinity with the Inuit culture, and heavily engaged in the Inuit Circumpolar Council (ICC). If we join Coastal Norway with our definition for the West Nordic, and despite some degree of cultural contact, it can be questioned to what extent there is enough "culture" to make up a region. All areas are parts of the general Nordic family, and, as already argued, the relations with Denmark are particularly strong. Iceland and the Faroes may actually be those countries having most cultural heritage in common, an affinity which seems to have been reinforced the last years by reciprocal aids in difficult times, starting with the Faroese unreserved support and aid to Iceland in the dark year of 2008.

Without any doubt, the social, historical and cultural relations between the three countries are strong and clear and have helped to create some kind of common identity. It is this regional affinity "from below" like Nordic cooperaton in general, which is at center stage of West Nordic cooperation.

\section{Conclusion and discussion}

Looking at the Vestnorden region from the perspective of functional integration, provides us with the picture of a fragmented space. So, if we ask whether Vestnorden can be characterised as a functional cross-border region in the sense we have been referring to, the answer is definitely no. If we search for formal decision making institutions and significant economic relations of the kind where the strength of one partner complements the weaknesses of the others, the answer is definitely no. 


\section{STJÓRNMÁL

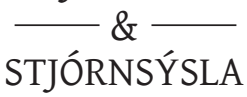

Economic complementarity is very limited. All countries are heavily dependent on fishing and fish processing, which means that they are competing on the same international markets. However, the countries have clear common economic interests. These interests would be to keep their seas safe and their fishing zones sustainable. Also, tourism cooperation is an obvious common field of interest, which has been somewhat growing, but it is only by good will that we can claim that common economic interests are slightly increasing here.

Although laden with power and always questionable, historical connotations are normally strong and rather unchanging impulses of unity and the element that most clearly depicts the West Nordic as a functioning region are their strong historical ties. From this perspective, Vestnorden is in reality and in practice, first and foremost something we could call a socio-cultural region.

The present status of West Nordic cooperation should be understood as a combination of the historical heritage, of which we have outlined some crucial aspects, and the Nordic tradition of 'low politics', meaning primarily cultural cooperation and weak institutionalisation. 'Weak' in this respect means something opposite towards 'strong' top-down oriented planning. Though, in the West Nordic optics we will argue weakness or low functionality in the sense that the institutional structures also appear fragmented, covering different geographical spaces in which their political, economic and cultural ties appear without any unity.

There are historical reasons for the weak functional status of the West Nordic region. It is a regional construct, which is the result of recognition and compromises from the East Nordic space, especially with respect to the non-national legal positions of Greenland and the Faroes. Although things have changed somewhat in the aftermath of the crisis, Iceland is a sovereign state which keeps its foreign policy interests in relation to other sovereign states, while Greenlandic and Faroese matters still are heavily related with Denmark. This is one reason why especially Iceland has been reluctant in increasing the competences of the West Nordic Council. The different legal statuses of the Vestnorden space make functionality difficult, and we may look at it as a region still in its making, hence much effort is still put into the identification dimension of its existence (see endnote iv). The mix of one state, two self-governing areas (and even sub-national regional levels if we include Coastal Norway into our definition) makes the sphere of interests and the performance of interests fragmented, and therefore weak. And in particular it is the weak legal status of Greenland and the Faroes, which makes increased functionality difficult.

The obvious example is the structure of the West Nordic Council. As a subset of the general Nordic cooperation, only having a recommending role on policy matters makes it far away from having any appreciable impact on the present changes taken place in the West Nordic space, not the least compared to the increasing role of the "high politics" Arctic Council.

Interestingly, and besides its focus on cross-border economic cooperation and innovation, the new West Nordic region (the NORA-region), has a clear mandate in extend- 


\section{STJÓRNSÝSLA}

ing the interests of the East-Norden space towards other parts of the Nordic Atlantic, the North Scottish Islands and Atlantic Canada. One could therefore argue that NORA represents the general Nordic (including West Nordic) interest in global political and economic restructuring, although still based on "low politics".

The last years we have witnessed a heavily increased interest in the construction of a new regional space, the Arctic region. The Arctic region covers generally the same sphere of interest as does Vestnorden with the Arctic Council as a clearly state-centred, top-down oriented and strong institution. The East-Nordic countries put great interest into this new high-politics area, which includes a common Arctic strategy of the Danish Kingdom (Denmark, Greenland and the Faroes).

Again, the problem here is that the West-Nordic countries follow different routes of influence on matters of great common interest, events which may push the West Nordic council even more on the outset. This may well be the reason why the Arctic agenda is recently taken up as a theme in the West Nordic Council. More forceful changes, we believe, will be put in front by the recent changes in especially Greenland and their global economic and political reach. These changes will probably continue to put the constitutional relations between Denmark and Greenland - and probably the Faroes also on the agenda, which in turn will affect the wider West Nordic and Nordic community.

For the reasons mentioned, we can raise the question whether the existing elements of significant decision making institutions are strong enough to make the West Nordic area a functionally integrated region in the nearest future. Evidently, it can be argued that a stronger region in functional terms is not even appropriate, because the regional policy of Vestnorden should continue to follow the lines and compromises of general Nordic cooperation. As we have argued, we believe there are a few key reasons why this argument may not be durable in the immediate future, or at least needs a more thorough discussion.

It is well known that regionalism and regional building is a matter of the social construction of space. But without reflecting upon and openly discussing the institutional functionality of the "old" West Nordic regional space in relation to the recent challenges enforced by the new global interest of the North, this Nordic hybrid may risk turning into a mere appendix of the new global mosaic of regions.

\section{Notes}

1 http://www.vestnordisk.is/Apps/WebObjects/SW.woa/wa/dp?id=1295

2 http://www.hagstova.fo/portal/page/portal/HAGSTOVAN/Hagstova_Foroya/Hagtalsgrunnur/ibugvav_val/Talva\%20BRBGDMD_05- (on 14th May 2013.)

3 http://dk.nanoq.gl (on 14th May 2013)

4 Thór, Thorleifsen, Mortensen and Marquardt (Eds). (2012) is a recent historical interpretation of Vestnorden. This volume, supported by the West-Nordic and Nordic community, can clearly be seen as part of the construction a common West Nordic identity.

5 Taken from http://www.nora.fo/en/index.php?pid=208 on 26th January 2012.

6 Also, Neumann (1994) argues that the foundation of overall Nordic cooperation is based on a long cultural collectivity as a means to achieve balance between the superpowers, as well as an attempt to create a Nordic region. 


\section{STJÓRNMÁL \& STJÓRNSÝSLA}

7 http://www.northatlantic-islands.com/about-nata.html. Downloaded on 26th May 2013.

8 http://www.nora.fo/en/index.php?pid=378 (on 3rd March 2013)

9 As parts of the general Nordic cooperation the West Nordic Countries can also by equal terms apply means from Nordic institutions like Nordic Innovation or NordForsk.

10 Calculated from http://www.hagstova.fo/portal/page/portal/HAGSTOVAN/Hagstova_Foroya/ news_repos/Inn- $\% 20 \operatorname{og}^{\%} \% 20 \%$ FAtflutningur $\% 20$ nov. $\% 202012$ (february 1 st, 2013)

11 The figures for Iceland are taken from the web www.hagstofa.is on 11th May 2013. http://hagstofa. is $/$ PageID $=2601 \& \mathrm{src}=/$ temp $/$ Dialog $/$ varval.asp?ma $=$ UTA02201\%26ti $=\%$ DAtflutningur + eftir +vinnslugreinum + mars $+2012 \% 2$ D2013\%26path=../Database/utanrikisverslun/Utflutningur $/ \%$ 26lang $=3 \% 26$ units $=$ Fob $\% 20$ ver $\%$ F0 $\% 20 \%$ ED $\% 20$ millj $\%$ F3num $\% 20 \mathrm{kr} \% \mathrm{~F} 3 \mathrm{na}$

12 http://www.flugfelag.is/upplysingar/um-flugfelag-islands/frettir/flugfelag-islands-flygur-til-nuukallt-arid

\section{References}

Aalbu H., Höydal E., Jussila H, \& Wiberg U.(1995). A velge sine naboer. Barentsregionen som utenrikspolitisk og regionalpolitisk prosjekt.(1995:4). Stockholm. NordRefo.

Aalbu, H. and Wiberg, U. (1997). How may Institutional Regionalization Promote Regional Development? Pp. $77-$ 101 in Dellenbrandt, J A and U Wiberg. (eds.) Euro-Arctic Curtains. Umeå. CERUM.

Apostle R., Holm D., Hovgaard G., Høgnesen O. W., and Mortensen B. (2002). The Restructuration of the Faroese Economy. The significance of the inner periphery. Copenhagen. Samfundslitteratur.

Arctic Council website: http//: www.arctic-council.org

Arabo, Thomas. Interview, May 26th 2006.

Arge, J.. 2002. Teir tóku land. Foroyingar i Gronland. Tórshavn: Tjarnardeild.

Association of European Border Regions (AEBR) (1999). Institutional aspects of cross-border cooperation. Downloaded from: www.aebr.eu/files/publications/inst_asp_99.en.pdf. on 1. February 2013.

Baldacchino, G. (2008). Population dynamics from Peripheral Regions: A North Atlantic Perspective. European Journal of Spatial Development. Downloaded from: http://www.nordregio.se/EJSD/refereed27. pdf at 11th December 2012.

Baldersheim, H., and Ståhlberg, K. (1999). Nordic Region-Building in a European Perspective. Aldershot. Ashgate.

Baltic Rim Economies (2011). Quarterly Review. Special Issue on the future of the Arctic. Issue No. 4.

Benedict, B. (ed.) 1967. Problems of Smaller Territories. London: Athlone Press for the Institute of Commonwealth Studies,

Bærenholdt, J. O. (2007). Coping with distances. Producing Nordic Atlantic Societies. Berghahn Books.

Bærenholdt, J. O. (2002). The Significance of Transnational Cooperation in Nordic Atlantic Regions. Pp 33-55 in Fróðskaparrit 50. Bók. Tórshavn: Annales Societatis Scientiarum Færoensis.

Dubois, A, Hedin, S., Schmitt, P., and Sterling, J. (2009). EU macro-regions and macro-regional strategies - A scoping study. NORDREGIO ELECTRONIC WORKING PAPER http://www.nordregio.se/en/ Publications/Publications-2009/EU-macro-regions-and-macro-regional-strategies/

Eythórsson, G.T., Gylfason, Th., and Jahn, D. (2011). Iceland report. Sustainable Governance Indicators 2011. Bertelsmann Stiftung. $\underline{\text { SGI }}$

Hanell, T. and Ringö, S. (2003): West-Norden And Its Neighbours. ANP 2003:733. Copenhagen. Nordic Council of Ministers

Heiðarsson, J. Th., and Jóhannesson, H. (2004). Fly- og skibstrafik i Vestnorden, bvorfra og bvorben? Analyse og prognose. ANP 2004:774. København: Nordisk Ministerråd.

Hettne, B. (1996). Globalization, the new regionalism and East Asia. United Nations University. Shonan Global Seminar.

Hovgaard, G. (2001). Globalisation, embeddedness and Local Coping Strategies. A comparative and qualitative study of local dynamics in contemporary social change. Ph.D Thesis. Roskilde: Department of Social Science. University of Roskilde. 


\section{STJÓRNSÝSLA}

Hovgaard, G, Eythórsson, G and Fellman, K (2004). Future challenges to small municipalities. The cases of Iceland, Faroe Islands and Aland Islands. Nordregio R2004:5.

Jacobsen, H. (2011). Ringar á sjónum. Sogan um foroysku alivinnuna. Havbúnaðarfelagið.

Jákupsstovu, J. (1966). Fiskeri. Pp. 70-81 in Færøerne i dag. Tórshavn. Norrøna Felagið.

Joensen, J. P. (1987). Fra bonde til fisker - studier i overgangen fra bondesamfund til fiskersamfund. Tórshavn: Føroya Fornminnissavn.

Joensen J. P.(1975). Faroske sluppfiskere. Etnologisk undersogelse af en erbvervsgruppes liv. Tórshavn: Annales Societatis Scientiarum Færoensis. Supplementum 6.

Katzenstein, P. 2003. Small States and Small States Revisited. New Political Economy. Vol. 8. No. 1. Carfax Publishing: Taylor \& Francis Group.

Kvistgaard Consult (2004). Evaluering og analyse av det nordatlantiske samarbejde NORA. Copenhagen. Nordisk Ministerråd.

Lindeborg, L. (2011). The Baltic Sea Region. A Global region - No Macroregion. Pp. 281-289 in Herrschel, T, and P Tallberg.. (eds.). The Role of the Regions? Networks, Scale, Territory. Kristiansstads Boktryckeri.

Lundqvist, L. \& Persson, L. O. (eds.) (1993). Visions and Strategies in European Integration. A North European Perspective. Berlin-Heidelberg: Springer-Verlag.

Neumann, I. B. (1994). A Region-building Approach to Northern Europe. Review of International Studies 20: 53-74.

NORA website. http://www.nora.fo

Nordic Statistical Yearbook, 2012.

http://www.norden.org/da/publikationer/publikationer/2012-001

Nordisk Ministerråd. (2003). Vest-Norden i det nordiske samarbejde. Redegörelse. ANP 2003:732.

OECD Territorial Reviews. (2011). NORA REGION. The Faroe Islands, Greenland, Iceland and Coastal Norway. OECD.

http://phg.sagepub.com/content/26/6/802.full.pdf on January 25, 2013.

Sakhuja, V. (2011). China's Arctic Calculus and Iceland. Society for the Study of Peace and Conflict (SSPC Issue Brief). Downloaded 23. February 2013 from http://www.sspconline.org/issuebrief/ChinasArcticCalculusandIceland.

Storper, M. (1997). The Regional World. Territorial Development in a Global Economy. New York London: The Guilford Press.

Sundström, E. (2006). Välfärdspolitiska förhållanden i V ästnorden. Färöarna, Grönland och Island Köpenhamn: Nordiska Ministerrådet.

Vestnordenfonden. Arsrapport 2012.

Vestnordic Council website: http//:www.vestnordisk.is

The Winston Dictionary. Encyclopedic Edition. Philadelphia. The John C Winston Company. 1943.

Thór, J. Th., Thorleifsen, D, Mortensen, A and Marquardt, O (2012). Naboer i Nordatlanten - Hovedlinjer i Vestnordens historie gennem 1000 år. Tórshavn. Faroe University Press.

Tønnessen, Joh. N. (1967). Den moderne hvalfangsts historie. Opprinnelse og utvikling. Annet bind. Sandefjord: Norges Hvalfangstforbund. 